\title{
Non-timber forest products extraction activities of traditional communities in the upstream Mamberamo Basin of West Papua, Indonesia
}

\author{
YOHANES Y. RAHAWARIN \\ Faculty of Forestry, the State University of Papua, Jl. Gunung Salju, Amban, Manokwari 98314, West Papua, Indonesia, Tel \& Fax.: +62-986-211364, \\ email: jo.rahawarin@gmail.com
}

Manuscript received: 1 May 2017. Revision accepted: 11 June 2017.

\begin{abstract}
Rahawarin YY. 2017. Non-timber forest product extraction activities of traditional communities in the upstream Mamberamo Basin of West Papua, Indonesia. Asian J For 1: 23-26. Forest provides a variety of resources that benefit traditional communities, including indigenous communities in Papua. The aim of this study was to investigate the utilization of non-timber forest products (NTFPs) by local communities in the upstream part of Mamberamo Basin, West Papua, Indonesia. Field surveys, direct observation and semi-structural interviews were conducted to generate data. The results showed that the local communities in the upstream part of Mamberamo Basin extract several non-timber forest products over the course of their generations to fulfill basic daily necessities and to generate cash incomes. Sago palm (Metoxylon sagu) was among the most important non-timber forest products which are used as a staple food, while hunting freshwater crocodiles (Crocodylus porossus) for its skin and collecting agarwood (Gyrinops sp.) were the primary activities to generate cash incomes. These activities have lasted for generations, so people called them traditional conservation. They are believed to be done on a sustainable basis to keep the availability of non-timber forest products to fulfill the daily needs over generations.
\end{abstract}

Keywords: Non-timber forest products, local communities, upstream part, Mamberamo Basin, traditional conservation

\section{INTRODUCTION}

Forest ecosystem is a life-supporting system that provides a wide range of ecosystem services, especially for the surrounding communities. The components of forest ecosystem, such as wild animals, plants, water, and soil, support a better socio-economic condition for the society (Rahawarin 2010a, 2010b). Tropical forest is very rich in flora and fauna, which can be utilized to fulfill human needs, such as timber and non-timber products (NTFPs) for the present and next generations (Masripatin 2007).

Papua is located in the eastern part of Indonesia with an area of over $421,981 \mathrm{~km}^{2}$. The vast area of Papua stretches over various types of ecosystems, from coastal to mountain ecosystems, including tropical rainforest with its rich biodiversity elements which serve as the source of livelihoods of traditional communities (Beno et al. 2009). Petocz (1987) and Conservation International (1999) reported that there are about 20,000-25,000 species of plants, 200,000 species of insects and invertebrates, 330 species of reptiles and amphibians, 650 bird species, and 164 mammals in the land of Papua.

Indigenous communities in Papua are highly dependent on forest resources. The utilization of forest products by local communities in Papua is not limited solely to the flora, but also to the fauna through traditional hunting. Pattiselanno (2003) claimed that hunting of some wild animals in the tropical rainforest in Papua gives a significant contribution to the communities, not only to provide protein but also to generate income for traditional households.

However, wild animal hunting warrants investigation since this practice is not necessarily sustainable in the long run. Studies by Robinson and Redford (1994) and Robinson and Bodmer (1999) showed that hunting in several tropical rainforests was not sustainable and wild animals will be very vulnerable to over-exploitation which can lead to extinction.

Departed from such issue, it is important to investigate the sustainability of forest resources in Papua in relation to the extraction activities, not only on animals but also on other components. Therefore this research was conducted to study the utilization of non-timber forest products (NTFPs) by local communities in the upstream part of Mamberamo Basin, West Papua, Indonesia.

\section{MATERIALS AND METHODS}

This study was conducted at the upstream part of Mamberamo River, administratively located in Bernakamp, Taive, and Dabra Districts of Mamberamo Raya Regency, West Papua. In general, the location is characterized by a rigged area dominated by mountains and small rivers flowing to the sea (Figure 1).

Field surveys, direct observation and interviews were applied in this study. Through field survey and observation, primary data of flora and fauna were taken. Socio- 
economic and cultural data were also gathered through oral interviews by asking the communities using key questionnaires. Sampling plots were made in the forests to collect data on the diversity and distribution of the flora, while for the fauna, enumeration technique was carried out which was based on the preliminary information given by the communities. The surrounding forests belonging to the Tabruta Tribe were surveyed based on their daily activities in the forests. Several tools were used in data collection including manual diameter tape, Haga altimeter, binocular camera, documentation tools, and stationery.

Secondary data on biophysical conditions of the surrounding forests in which extraction activities were carried out by the communities were collected through literature research of documents from relevant stakeholders. The data were analyzed descriptively.

\section{RESULTS AND DISCUSSIONS}

\section{Distribution of Non-Timber Forest Products}

The main distribution of Non-Timber Forest Products (NTFPs) is located upstream of Mamberamo Basin. This area consists of various landscapes, including lowland forest, swamp forest, and man-made agricultural lands (Figure 1). Based on a report published by the Agricultural Service of Mamberamo Raya District (2012), the total area is about $317,353 \mathrm{Ha}$ which is dominated by lowland forest (96.68\%) from the Plateau of Taribu Mountain at Taria Village, Bernakamp village to the Rotia Mountain in the Dabra area. Swamp forest $(2.64 \%)$ is distributed in the Mamberamo Basin along the tributaries which flow to the northern part which form many small lakes. These areas are used for farming Mozambique tilapia (Oreochromis mossambicus), common carp (Cyprinus carpio), and freshwater crocodiles (Crocodylus porosus). There are around 20-25 lakes regularly used to fulfill the household needs. The total area intended for fish and crocodile farming is about 1-2 Ha. In addition, the swamp forest around the upstream of the river are planned for cultivation of sago (Metroxylon sagu Rottb.), and a handful of areas is allocated for hunting wild boar (Sus scrofa). The locations for sago are quite limited which are around the lowland forest.
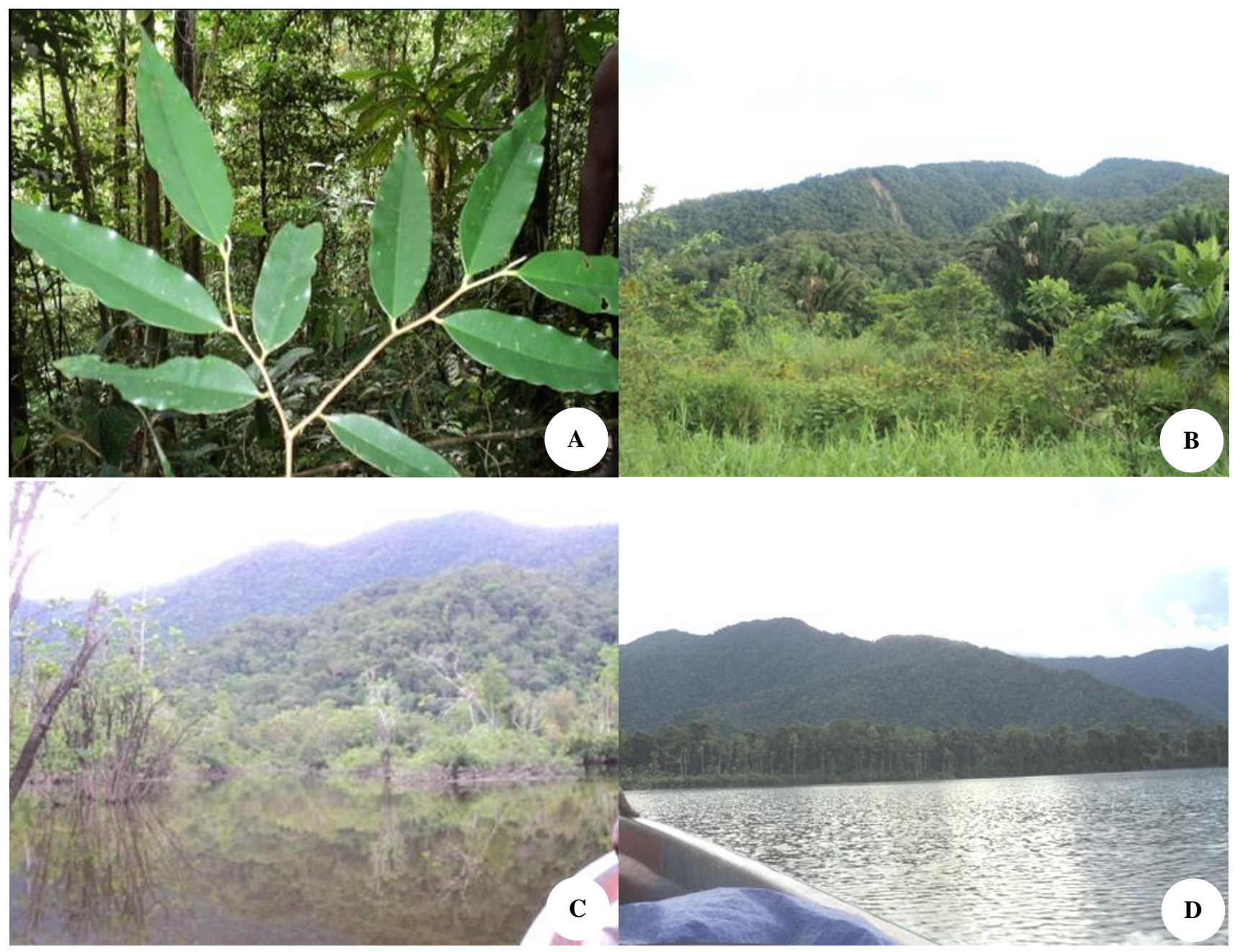

Figure 1. A. The vegetation condition of Taribu Mountain; B. The landscape of Rotia Mountain; C-D. The lowland tropical forest viewed from the upstream of Mamberamo river, West Papua, Indonesia 
The percentage of NTFPs from agriculture sector is only $0.58 \%$, mainly used as the source of carbohydrates, vegetables and protein, including protein from animals. The total cultivating area for each household is approximately around 0.25-0.5 ha.

The previous studies by Allen et. al. (2002) and Binur and Ohee (2010) reported that there were 22 species of NTFPs found the upstream of Mamberamo River (Table 1). Based on the interviews in this study, the communities consider NTFPs commodities as the primary source to generate household income, namely the extraction of agarwood and crocodile skin for accessories. Other products also generate income, but are less significant, such as the yields from gardening, hunting and fishing.

\section{Utilization of Non-Timber Forest Products}

The communities who live upstream of the Mamberamo River extract the NTFPs based on their traditional ways and beliefs. For example, agarwood from the lowland forest is extracted using traditional ax or blade by cutting the tree and taking out the resin then sold it. There are no specific skills needed for the management and processing.
Sago as the major source of staple food for the traditional communities is extracted using simple traditional methods by cutting down the tree using an ax, rinsing with water to disentangle the starch and sago residue, and packing the starch with a traditional bag made from sago leaves. Besides the starch, the midribs of Sago plants are used to make roofs of the traditional houses around the Mamberamo River. Those processes are managed in the traditional way without formal education. Instead, the information is just passed from generation to generation within the communities.

Crocodiles hunting activities are carried out by setting the fishing equipment or catching them directly from rivers, usually in the evening. The animals are then transported to the house in order to take out the skin. The young crocodile's meat is cooked or grilled for consumption. The skin is preserved by pouring it with salt then covering it with a plastic bag.

Generally, the upstream communities in Mamberamo do not work as fishermen to get cash income, but they do fishing only to fulfill their daily needs (Polhemus and Richards 2001). Other NTFPs intentionally planted in the surrounding area are Areca catechu, taro and cassava for consumption.

Table 1. List of Non-Timber Forest Products utilized by indigenous communities in the upstream river of Mamberamo, West Papua, Indonesia

\begin{tabular}{|c|c|c|c|}
\hline \multicolumn{2}{|c|}{ Name of species } & \multirow{2}{*}{ Parts of plants } & \multirow{2}{*}{ Purposes } \\
\hline English name & Scientific name & & \\
\hline Agarwood & Gyrinops sp. & Resin and tree bark & $\begin{array}{l}\text { The resin is traded whereas the tree bark is used for walls of } \\
\text { houses. }\end{array}$ \\
\hline Betel palm & Areca catechu & Fruits & $\begin{array}{l}\text { Chewed in pinang-sirih activities either for self-consumption or } \\
\text { for sale. }\end{array}$ \\
\hline Cananga & Cananga odorata & Stems and bark fiber & $\begin{array}{l}\text { Stems are used for construction materials and bark fiber for } \\
\text { material and traditional bag (noken). }\end{array}$ \\
\hline Crocodile & Crocodylus porosus & Meat and scale, skin & Meat is eaten and skin is sold. \\
\hline Dammar & Vatica rassak & Sap & Used to make candles for light. \\
\hline Figs & Ficus sp. & $\begin{array}{l}\text { Tree bark and fiber } \\
\text { bark }\end{array}$ & $\begin{array}{l}\text { Tree bark is used for covering the food whereas the bark fiber is } \\
\text { made into traditional bag and clothes. }\end{array}$ \\
\hline Fijian longan & Pometia pinnata & Fruits & Used as edible fruit \\
\hline Common carp & Cyprinus carpio & Meat & Meat is eaten and sold. \\
\hline Guava & Syzygium sp. & Fruits & Used as edible fruit. \\
\hline Masohi & Cryptocarya sp. & Bark & The bark is sold. \\
\hline Melinjo & Gnetum gnemon & $\begin{array}{l}\text { Bark fiber, leaves and } \\
\text { fruits }\end{array}$ & Leaves and fruits are edible. Bark fiber is made into noken. \\
\hline $\begin{array}{l}\text { Mozambique } \\
\text { tilapia }\end{array}$ & $\begin{array}{l}\text { Oreochromis } \\
\text { mossambicus }\end{array}$ & Meat & Meat is eaten and sold. \\
\hline Orchid & Dendrobium sp. & All parts of the plant & Used as decorative plant \\
\hline Palm & Orania sp. & All parts of plant & $\begin{array}{l}\text { Leaves and midribs are used for construction materials, whereas } \\
\text { stems are used to make bows and arrows. }\end{array}$ \\
\hline Palm & Hydriastele sp. & $\begin{array}{l}\text { Stems and all parts } \\
\text { plant }\end{array}$ & $\begin{array}{l}\text { Steams are used for construction and hand-made crafts. Palm is } \\
\text { used for home decoration. }\end{array}$ \\
\hline Palm & Linospadix sp. & Leaves & Leaves are used for construction. \\
\hline Rattan & Korthalsia zippeli & Stems & $\begin{array}{l}\text { Stems are used for materials and construction, i.e., chairs, tables, } \\
\text { and fences. }\end{array}$ \\
\hline Red fruit & Pandanus sp. & Fruits and leaves & Fruits are edible and leaves are used for housing floor materials. \\
\hline Sago & Metroxylon sp. & $\begin{array}{l}\text { Sago starch, leaves, } \\
\text { stems midribs and } \\
\text { trunks }\end{array}$ & $\begin{array}{l}\text { Sago starch is commonly used as a staple food and sold; leaves } \\
\text { and midribs are used for construction materials; steams are } \\
\text { applied for media, sago caterpillar for food protein. }\end{array}$ \\
\hline Stinging tree & Laportea indica & Leaves & Used as traditional medicine. \\
\hline Wild boar & Sus scrofa & Meat and teeth & $\begin{array}{l}\text { Meat is eaten and sold, while teeth are used for } \\
\text { accessories/souvenirs. }\end{array}$ \\
\hline $\begin{array}{l}\text { Yellow fruit } \\
\text { moonseed }\end{array}$ & Arcangelisia sp. & Stems & Used as traditional medicine \\
\hline
\end{tabular}




\section{Traditional conservation of NTFPs}

With regard to the availability of NTFPs, conservation and preservation actions are required. There are a number of solutions in order to keep the benefit of NTFPs while maintaining future availability for generations to come. It is clear that the utilization of NTFPs for self-consumption and small-scale commercial activities are managed in a sustainable way by considering the natural capacity. However, extensive activities and cultivation are mandated to do in the communities to reduce the over-exploitation in the natural habitat. Land is continuously managed for growing some edible crops and domesticated animals. For example, during dry season when level of water in the river is reduced, the communities tend to alter their daily activities into the swamp forests and rivers. On the other hand, during rainy season the communities are focused on the high land to extract NTFPs.

The communities believe that by managing the forest and nature in a sustainable way, they will continuously get benefits from them. Such beliefs that traditional communities carry have been made into some traditional regulations and customs. For example, every hunting activity should get permission from the traditional leader. Sumule (1995) and Pattiselano (2006) reported that some areas in Papua belong to certain ethnic groups or clans; therefore, besides requesting the permit, they also should share some of their hunting product with the communal landholders.

\section{REFERENCES}

Allen G, Ohee H, Boli P, Bawole R, Warpur M. 2002. Fishes of the Yongsu and Dabra areas, Papua, Indonesia. In: Richards SJ, Suryadi S (eds.). A Biodiversity Assessment of Yongsu - Cyclops Mountains and the Southern Mamberamo Basin, Papua, Indonesia. RAP Bulletin of Biological Assessment No 25., Washington DC.

Beno M, Ohee H. 2009. Traditional Conservation Knowledge of Endemic Birds for the Community at Soaib Village in Kemtuk District, Jayapura. J Papua Biol 1 (1): 15-20.

Binur R, Ohee HL. 2010. The diversity of freshwater fishes in Haya, Mamberamo-Papua. Jurnal Natural 9 (1). DOI: 10.30862/jn.v9i1.319

Chahya DN. 2000. Teknologi Berburu Rusa (Cervus timorensis) dan Kasuari (Casuarius sp.) Secara Tradisional Pada Masyarakat Suku Marind dan Kanuum di Kawasan Taman Nasional Wasur Kabupaten Merauke. [Skripsi]. Fakultas Kehutanan, Universitas Negeri Papua, Manokwari. [Indonesian]

CI. 1999. Lokakarya Penentuan Prioritas Konservasi Keanekaragaman Hayati di Irian Jaya. [Laporan Akhir]. Conservation International, Jakarta. [Indonesian]

Dinas Pertanian Kabupaten Mamberamo Raya. 2012. Data Base Pembangunan Pertanian Kabupaten Mamberamo Raya. Kerjasama Pemerintah Kabupaten Mamberamo Raya dan Universitas Negeri Papua, Manokwari. [Indonesian]

Pattiselanno F. 2003. The Wildlife value: example from West Papua, Indonesia. Tigerpaper 30 (1): 27-29.

Pattiselanno F. 2006. The wildlife hunting in Papua. Biota 11: 59-61.

Petocz RG. 1994. Konservasi Sumberdaya Alam dan Pembangunan di Irian Jaya. Graffitti Press, Jakarta. [Indonesian]

Polhemus DA, Richards SJ. 2002. Ulasan Geografis Pegunungan Cyclops dan Daerah Aliran Sungai Mamberamo. In: Richards SJ, Suryadi S (eds.). A Biodiversity Assessment of Yongsu - Cyclops Mountains and the Southern Mamberamo Basin, Papua, Indonesia. RAP Bulletin of Biological Assessment No 25., Washington DC.

Rahawarin Y. 2010a. Forest land use by the community in Sorong National Tourism Park at Sorong City, West Papua Province. Biodiversitas 11 (4): 222-227. DOI: 10.13057/biodiv/d110410.

Rahawarin Y. 2010b. Strategi pengelolaan hutan tropika sebagai komponen penyimpan karbon. Agripura 6 (1): 798-806. [Indonesian]

Robinson JG, Redford KH. 1994. Measuring the sustainability of hunting tropical forests. Oryx 28: 249-256. DOI: 10.1017/S0030605300028647.

Robinson JG, Bodmer RE. 1999. Towards wildlife management in tropical forest. J Wildlife Manag 63: 1-13. DOI: 10.2307/3802482.

Sumuel AI. 1995. The technology adoption behavior of the indigenous people of Irian Jaya: A case study of the Arfak Tribal. Faculty of Agriculture, Universitas Cenderawasih, Manokwari. 